Please do not remove this page

RMIT

UNIVERSITY

\title{
Measuring absorptive capacity constraints to foreign aid
}

Feeny, Simon; De Silva, Ashton

https://researchrepository.rmit.edu.au/esploro/outputs/9921858560601341/filesAndLinks?institution=61RMIT_INST\&index=null

Feeny, S., \& De Silva, A. (2012). Measuring absorptive capacity constraints to foreign aid. Economic Modelling, 29(3), 725-733. https://doi.org/10.1016/j.econmod.2012.01.013

Document Version: Accepted Manuscript

Published Version: https://doi.org/10.1016/j.econmod.2012.01.013

Repository homepage: https://researchrepository.rmit.edu.au

(C) 2012 Elsevier B.V. All rights reserved.

Downloaded On 2023/04/26 19:14:11 +1000

Please do not remove this page 
Thank you for downloading this document from the RMIT Research Repository.

The RMIT Research Repository is an open access database showcasing the research outputs of RMIT University researchers.

RMIT Research Repository: http://researchbank.rmit.edu.au/

\section{Citation:}

Feeny, S and De Silva, A 2012, 'Measuring absorptive capacity constraints to foreign aid', Economic Modelling, vol. 29, no. 3, pp. 725-733.

See this record in the RMIT Research Repository at:

http://researchbank.rmit.edu.au/view/rmit:16253

Version: Accepted Manuscript

Copyright Statement: (c) 2012 Elsevier B.V. All rights reserved.

Link to Published Version:

http://dx.doi.org/10.1016/j.econmod.2012.01.013

\section{PLEASE DO NOT REMOVE THIS PAGE}




\title{
Measuring Absorptive Capacity Constraints to Foreign Aid
}

\author{
Simon Feeny* and Ashton De Silva \\ School of Economics, Finance and Marketing \\ RMIT University
}

\begin{abstract}
To assist with progress towards the United Nations Millennium Development Goals (MDGs) in developing countries, the international community is scaling-up foreign aid to record levels. Concurrently, there are concerns that additional aid will not be used effectively due to a problem of absorptive capacity in recipient countries. Empirical studies lend support to these concerns with many finding that there are diminishing returns to foreign aid. This paper reviews the extensive aid effectiveness literature to identify the various dimensions of absorptive capacity. It proceeds by devising a composite index of absorptive capacity for individual recipient countries which can assist policymakers in guiding the allocation of their aid. The relevance of the index is confirmed through its employment in a standard empirical model of aid effectiveness. The paper highlights the developing countries that currently receive high levels of aid relative to their estimated level of absorptive capacity.
\end{abstract}

Keywords: Foreign aid; absorptive capacity; developing countries; economic growth

JEL Classification Codes: F35; O11; O40.

*Correspondence should be sent to Simon Feeny, School of Economics, Finance and Marketing, RMIT University, Level 12, 239 Bourke Street, Melbourne, VIC 3000, Australia. Tel: +61 (3) 9925 5901, Fax: +61 (3) 9925 5986. Email: simon.feeny@,rmit.edu.au

Funding: This paper is part of an Australian Development Research Award (ADRA) research project generously supported by the Australian Agency for International Development (AusAID). The views represent those of the authors and not necessarily those of AusAID. 


\section{Introduction}

In 2009, total Official Development Assistance (ODA) from members of the OECD's Development Assistance Committee (DAC) increased to US $\$ 119.6$ billion, the highest amount of annual assistance ever recorded (OECD, 2011a). The increase in aid has been met with widespread support as efforts intensify to achieve the United Nations' Millennium Development Goals (MDGs) by 2015. However, there are also concerns within the policy community around whether additional aid will be used effectively in some countries due to a problem of absorptive capacity. Such concerns are reinforced by a number of recent academic studies that examine the impact of foreign aid on economic growth. A robust empirical finding from the empirical aid effectiveness literature is that there are diminishing and eventually negative returns to foreign aid. ${ }^{1}$ The relationship between the level of aid and its incremental impact on growth takes the form of an inverted-U shape. This implies that past a certain level, the incremental impact of aid starts to fall and donors start getting 'less bang for their buck'.

This finding has important implications for the inter-country allocation of aid. As donors continue to scale-up their assistance, it is important that the effectiveness of aid at promoting growth and reducing poverty is not compromised by over-aiding recipients relative to their levels of absorptive capacity (Feeny and McGillivray, 2011). In order to maximize the impact of aid, therefore, absorptive capacity should be included in models and formulae which guide the allocation of aid across countries. This necessitates the measurement of absorptive capacity at the country level which is the primary objective of the paper.

A number of aid allocation models have been proposed by the academic literature (Cogneau and Naudet, 2007; Collier and Dollar, 2002; Llavador and Roemer, 2001; and Wood, 2008). Variants of these models have been adopted by some multilateral and bilateral aid donors. Based on these models, aid allocation formulas are derived which seek to guide the allocation of annual aid budgets across recipient countries according to their size, their level of need and their ability to use aid effectively (often referred to as performance) This latter component is usually determined by a recipient's policy and institutional environment.

Yet, there are a number of Absorptive Capacity Constraints (ACCs) that might limit the ability of recipient countries (and donor agencies) to put aid flows to good use. These ACC are not currently accounted for in aid allocation models. This paper reviews the extensive literature on

\footnotetext{
${ }^{1}$ See for example, Hansen and Tarp (2000, 2001), Dalgaard and Hansen (2001), Lensink and White (2001), Hudson and Mosley (2001), Roodman (2004), Clemens et al. (2004) and Dalgaard et al. (2004).
} 
aid effectiveness to distinguish between the following five types of ACC: (i) human and physical capital constraints; (ii) policy and institutional constraints; (iii) macroeconomic constraints; (iv) deficiencies in the manner in which the international donor community delivers its foreign assistance; and (v) social and cultural constraints. A combination of these constraints in recipient countries limits the effectiveness of additional aid, justifying the development of a Composite Index of Absorptive Capacity (CIAC) for individual countries. The relevance of the index is confirmed through its employment in a standard empirical model of aid effectiveness.

Donors currently using existing indices and models to guide the allocation of their aid include the US's Millennium Challenge Account (MCA) whereby low income countries are rated according to a number of criteria relating to governing justly, investing in people and promoting economic freedom. Another is the World Bank's system of Performance-Based Allocations for its aid distributed to low income countries. This is largely based on its Country Performance and Institutional Assessment (CPIA) ratings. ${ }^{2}$ Since absorptive capacity is a crucial determinant of aid effectiveness, the adoption of the CIAC into such models can help maximize the impact of aid across countries.

The remainder of this paper is structured as follows: Section 2 reviews the academic literature to identify the various dimensions of absorptive capacity. Section 3 discusses the methodology adopted in this paper to develop a CIAC. The data and empirical techniques employed are also examined. Section 4 employs the CIAC in a standard empirical model to confirm its relevance to aid effectiveness. The section also provides rankings of developing countries according to their level of absorptive capacity and implications for the levels of aid that they are currently receiving are discussed. Finally, Section 5 concludes by suggesting a number of possible responses to absorptive capacity from the international community.

\section{Dimensions of absorptive capacity}

The existence of ACCs and diminishing returns to foreign aid has long been recognised. Chenery and Strout (1966) first documented diminishing returns to aid caused by the problem of absorptive capacity over 40 years ago. However, the issue is becoming increasingly pertinent as international donors scale up their aid to record levels and, arguably, it is a problem that has largely been ignored by policymakers. In economics, the concept of absorptive capacity is well known and often relates to the ability of a country to utilise capital productively. It is often found

\footnotetext{
${ }^{2}$ CPIA ratings are based on sixteen indicators relating to economic management, structural policies, policies for social inclusion and public sector management and institutions.
} 
that there are diminishing returns to capital. In other words, the productivity of capital (investment) falls as its level increases. Since international donors often fund capital and investment, this interpretation of absorptive capacity can readily be applied in the context of foreign aid. However, not all foreign aid is provided to fund profitable investment opportunities and therefore a broader view of the concept is required. This section reviews the extensive literature that investigates the effectiveness of foreign aid to identify the various ACCs which might exist in developing countries. It starts by examining the studies that have identified ACCs by establishing the existence of diminishing returns to foreign aid using cross-country data. It proceeds by discussing the findings from studies that have identified the existence of specific ACCs.

The vast majority of the aid effectiveness literature has examined the impact of foreign aid on per capita economic growth rates in recipient countries. Virtually all studies that test for diminishing returns confirm the existence of such a relationship (with respect to growth), providing strong empirical evidence for the existence of ACCs in recipient countries (see, for example, Hansen and Tarp, 2000, 2001; Lensink and White, 2001; Dalgaard and Hansen, 2001; Hudson and Mosley, 2001; Dalgaard et al, 2004; Roodman, 2004; and Clemens et al, 2004; and Feeny and McGillivray, 2010). ${ }^{3}$

These studies typically estimate the following equation:

$$
g_{i}=\alpha+\beta_{1} a_{i}+\beta_{2} a_{i}^{2}+\beta_{3}^{\prime} Z_{i}+\mu_{i} \quad i=1, \ldots, n
$$

where $g_{i}$ is per capita GDP growth in aid receiving country $i, a_{i}$ is aid relative to GDP to that country, $Z_{i}$ is a vector of additional variables, $\mu_{i}$ is a residual, $\alpha$ is a constant and $\beta_{1}, \beta_{2}$ and $\beta_{3}$ are coefficients. The signs of $\beta_{1}$ and $\beta_{2}$ are found to be positive and negative, respectively implying an inverted-U shaped relationship between aid and growth depicted in Figure 1 below.

\footnotetext{
${ }^{3}$ The vast aid effectiveness literature consists of other studies which find the impact of foreign aid on growth varies according to a number of recipient country characteristics. These characteristics include whether the recipient is located in the tropics (Dalgaard et al., 2004), its level of structural vulnerability (Guillaumont and Chauvet, 2001), the degree of democracy (Svensson, 1999) and whether it is experiencing a post-conflict period (Collier and Hoeffler, 2004). The literature also includes a minority of studies which fail to find a statistically significant relationship between aid and growth (Easterly et al. 2004; Rajan and Subramanian, 2008).
} 
The incremental impact of aid on growth increases for all levels of aid up to the threshold $a^{*}$. Once this threshold is reached, diminishing returns sets in and the incremental impact of aid starts to fall due to the existence of absorptive capacity constraints If donors have the objective of maximizing growth in recipient countries, they should provide aid up to (but no beyond) the level $a^{*}$. It is possible that other (non-growth) considerations as well as political factors might justify levels of aid in excess of $a^{*}$, at least in the short term. However levels of assistance which exceed $a^{* *}$ are very hard to justify since it provides the level of assistance at which negative returns sets in. At such high levels, aid might actually be doing more harm than good.

Figure 1: The relationship between foreign aid and economic growth

Contribution to Growth

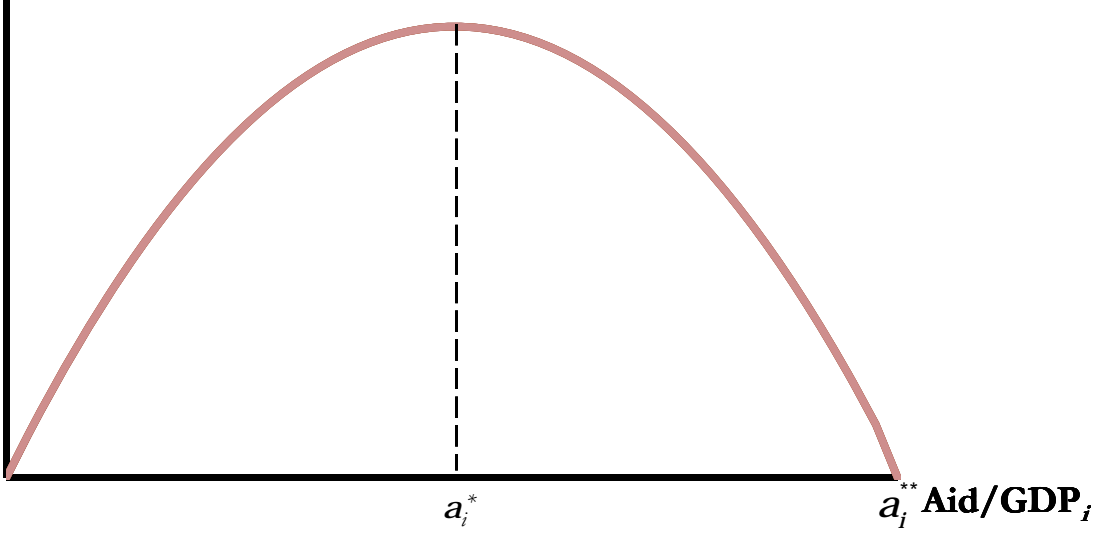

Source: Feeny and McGillivray (2011)

From equation (1) it follows that ceteris paribus:

$$
\mathrm{a}_{\mathrm{i}}^{*}=\frac{-\beta_{1}}{2\left(\beta_{2}\right)}
$$

and:

$$
\mathrm{a}_{\mathrm{i}}^{* *}=\frac{-\beta_{1}}{\beta_{2}}
$$

Equations (2) and (3) imply that $a^{* *}$ must be twice the level of $a^{*}$.

Various estimates of $a^{*}$ are provided by empirical studies. Drawing on the parameter estimates from a number of these studies, Feeny and McGillivray (2011) estimate that diminishing returns 
set in when foreign aid accounts for about 20 per cent of a recipient's GDP and that donors should exercise caution in providing a level of aid in excess of this threshold. However, since this threshold is estimated from studies using cross-country data, it represents an average threshold for developing countries as a group. The specific level of aid at which diminishing returns begin will vary across recipient countries. This provides the motivation for constructing an index of absorptive capacity for individual countries. ${ }^{4}$

Aid effectiveness studies point to a number of different capacity constraints which help explain the finding of diminishing returns to foreign aid. The following types of capacity constraints are identified: capital constraints; policy and institutional constraints; macroeconomic constraints; donor practices; and social and cultural constraints. ${ }^{5}$ Each type of ACC is discussed below.

\subsection{Capital constraints}

Capital constraints include human and physical capital constraints. Low levels of human capital might prevail in recipient country public sectors limiting their ability to put additional amounts of aid to good use. For example, at a central (administrative) level, public sectors might face a shortage of skilled or adequately trained civil servants to manage and administer foreign aid flows from overseas. Given the way in which flows are administered, public sector officials are likely to be responsible for a broad range of reporting requirements to different aid donors. They will also be responsible for hosting donor missions and dealing with staff from overseas agencies. All of these activities will take valuable time and resources away from core government tasks and functions. Recipient public sector staff might also lack the necessary skills and technical expertise for aid project identification, preparation and evaluation (Reyes, 1993). The constraint becomes more binding with poor donor practices in delivering aid, discussed below. Reducing this and the institutional administrative burden of aid is one of the objectives of the Paris Declaration on Aid Effectiveness to improve its quality.

Human capital constraints also exist at a sector level. In particular, recipient country health and education sectors are increasingly being targeted as donors seek to assist with progress towards the MDGs. However, a lack of qualified or trained staff in health and education in some

\footnotetext{
4 The strong evidence for the existence of ACCs should not provide grounds for donors to abandon the scaling up of their aid programs. Feeny and McGillivray (2011) note that if ODA accounted for 20 per cent of GDP in all recipient countries, the global aid budget would need to increase to US\$1,466 billion. This is a level far in excess of the levels implied by an outright doubling of aid, or where it accounts for 0.7 per cent of all donors GNI.
}

${ }^{5}$ See de Renzio (2005) and Bourguignon and Sundberg (2006) for other reviews and typologies of ACCs. 
countries will impede the effectiveness of additional resources aimed at achieving these goals. Such concerns are substantiated by the McKinsey Group (2003), which finds that human resources are the primary barrier to scaling up immunisation programs (cited in Dreesch et al., 2005). Moreover, Killick (2005) argues that there is a worsening shortage of human resources in Africa compounded by the brain drain and high mortality rates.

Physical capital constraints relate largely to infrastructure constraints. Extensive and well maintained infrastructure will play an important role in ensuring additional financial resources will lead to tangible progress towards the MDGs. Delivering essential services such as health, education, water and sanitation will require physical infrastructure (such as schools, hospitals and clinics) but also transport infrastructure (such as roads, bridges and ports). Improving telecommunications, energy infrastructure and irrigation systems will also assist in improving productivity and securing economic growth. In the absence of such infrastructure, the costs in delivering services to intended beneficiaries in rural areas will remain very high.

\subsection{Policy and institutional constraints}

A well cited finding in the empirical aid effectiveness literature is that weak macroeconomic policy and institutional environments undermine the positive impact of foreign aid (Burnside and Dollar, 2000, 2004; Collier and Dollar, 2002). While the robustness of this finding is often disputed, there is a widely held view that recipient countries should have appropriate economic and social policies in place in order to maximise the contribution of additional aid.

Strong institutions offer incorporate effective financial management systems; strong systems of accountability and transparency; high levels of law and order; a strong legal and judicial environment; and a democratic electoral process. Mechanisms also need to be in place to deal with the administration of aid programs including long-term national development plans and medium-term development strategies to which aid programs can be aligned. An effective planning department is also required to ensure that aid is aligned with national priorities and is coordinated effectively among different donors. For these reasons, the absence of effective policies and institutions can limit the effectiveness of additional aid. ${ }^{6}$

\footnotetext{
${ }^{6}$ While aid can be used to improve policies and institutions in recipient countries, at high levels it can also become part of the problem, leading to institutional destruction and weak systems of domestic accountability. A number of studies identify adverse impacts of foreign aid on institutions and the level of governance in recipient countries (Knack, 2000; Bräutigam and Knack, 2004; Killick, 2005; Stockmayer, 2005; Moss et al., 2006). These findings are not entirely undisputed (see Tavares, 2003; Coviello and Islam, 2006) but they do point to a need to be cautious
} 
The response of a recipient's fiscal policy to aid is another important aspect of this constraint. Specifically, recipient governments can change their spending and revenue raising behaviour in response to foreign assistance. If foreign aid is fungibile, it might lead to an increase in expenditures viewed as undesirable by donors or recipients might devise inappropriate expenditure plans. Additional aid flows might also increase the scope for corruption and financial mismanagement. Arguably the most important concern is whether large amounts of aid reduce the amount of tax collection efforts by recipient governments. Very low tax bases relative to aid flows can also lead to a high level of aid dependency, undermining democracy since recipient governments become more accountable to their aid donors than to their own electorates. ${ }^{7}$

\subsection{Macroeconomic constraints}

Very high levels of foreign aid can potentially have adverse macroeconomic impacts. Such impacts are widely referred to as Dutch disease impacts of aid. High levels of assistance can lead to an appreciation of a recipient's Real Exchange Rate (RER) and therefore to a loss of export competitiveness (Heller, 2005). This problem arises when the increase in demand for a recipient's currency leads to a nominal exchange rate appreciation and when aid is spent on domestic (non-tradeable) goods and services, thereby increasing their price and raising costs, or drawing resources away from the export (tradeable) sector. Given the importance of the export sector in many developing countries, these so-called Dutch disease impacts could undermine the positive impacts of aid on growth and poverty education.

However, the findings in the literature relating to macroeconomic constraints are ambiguous. Evidence of the Dutch disease impacts of aid are confirmed by Rajan and Subramanian (2005) for a sample of developing countries, by Adenauer and Vagassky (1998) for a sample of African countries, by Laplagne et al. (2001) for some Pacific countries, and by White and Wignaraja (1992) in the case of Sri Lanka. However, little or no evidence of aid-induced Dutch disease has been found by Ouattara and Strobl (2003) and Killick and Foster (2007) in samples of African

when scaling-up, in order to ensure that additional aid does not undermine the objective of strengthening institutions.

${ }^{7}$ The empirical evidence on the relationship between aid and tax is mixed. Results from fiscal response studies are clearly recipient specific, with aid found to lead to either increases or falls in tax revenues depending on the sample of countries under consideration. Using other techniques, Bräutigam and Knack (2004) found that higher levels of aid are associated with lower shares of tax to GDP in developing countries, while Bourguignon et al. (2005) identified that tax effort increased when aid increased in a study of 11 African countries. 
countries, by Nyoni (1998) in the case of Tanzania, and by Sackey (2002) in the case of Ghana. Mixed results have been identified for Pacific countries by Fielding (2007).

Arguably, there are other more important constraints to expanding the export sector in developing countries and the adverse effects of aid on a recipient's RER may be overstated. Barder (2006) argues that it is very unlikely that increases in foreign aid will lead to Dutch disease impacts if aid flows are sustained and predictable. Gupta et al. (2006) demonstrate that the likelihood of Dutch disease impacts from aid depends on how much aid is spent (rather than accumulated as reserves) and how much is 'absorbed' (where foreign exchange is used to purchase imports). Whether the recipient economy is supply constrained is likely to be an important factor mediating the impact of aid on the recipient's RER and its export competitiveness.

\subsection{Donor practices}

An additional constraint on the ability of recipients to absorb more aid effectively stems from the way in which aid is delivered by the international community. Developing countries are usually recipients of aid from a large number of donors. As noted above, the delivery of aid imposes an administrative burden on recipient country public sector officials. This administrative burden becomes larger when donors work in isolation from one another and use different procedures for monitoring and evaluation. As donors scale-up foreign aid, the burden will be further exacerbated by an increasing number of donors and a high degree of donor proliferation and fragmentation. The 2005 Paris Declaration on Aid Effectiveness seeks to minimise this burden.

Donor proliferation relates to donors providing aid to a large number of recipient countries, implying that each individual recipient has to deal with a large number of donors. Fragmentation refers to donors funding a large number of projects and programs across different sectors, which often results in duplication. There is a growing body of literature which documents the constraints caused by poor donor practices. The impacts and degree of donor proliferation and fragmentation have been identified by Morss (1984), Knack and Rahman (2004), Acharya et al. (2006) and Roodman (2006). Importantly, donor proliferation and fragmentation are likely to increase in the future with the scaling up of aid. 
Donors are also responsible for other aspects of aid delivery which could hamper its effectiveness. Volatile and unpredictable aid flows have a disruptive impact on annual budgets and fiscal planning. Studies have identified a high degree of volatility in aid flows, which hampers aid effectiveness and has been shown to increase over time (Lensink and Morrissey, 2000; Dollar and Levin, 2005; Bulír and Hamann, 2008; Fielding and Mavrotas, 2008). Aid flows are found to be more volatile than other sources of government revenue and volatility is also likely to increase with the scaling up of aid. In summary, the constraints engendered by poor donor practices on the ability of countries to absorb more aid are clearly important, and this remains undisputed in the literature.

\subsection{Social and cultural factors}

Social and cultural factors also represent a constraint on the effective use of additional aid flows. These constraints relate to a lack of demand for health and education services in some developing countries. Even if school and clinics are built and are well staffed, people may not necessarily attend them (de Renzio, 2005; Clemens et al., 2007). Relieving such constraints lies beyond the scope of international donors but should be a consideration when scaling up aid programs in particular countries.

\section{Measuring the absorptive capacity of developing countries}

It is important to clearly motivate the development of the paper's CIAC, given recent critiques of composite or 'mashup' indices (Ravallion, 2010). The CIAC is developed in order to assist donors allocating their annual aid budgets across developing countries. This is important given the strong evidence of diminishing returns to aid and that that low levels of absorptive capacity limit aid effectiveness. The CIAC is designed to capture the most important factors which inhibit the effectiveness of aid at a country level. Importantly, country rankings, based on the CIAC are shown to be robust to different weightings of the index components. The index can be used to augment existing aid allocation models and replace other ad hoc measures of institutional capacity and policy strength. Ceteris paribus, higher levels of aid should be provided to countries with higher levels of absorptive capacity and vice versa.

The index needs to meet a number of criteria to be of use for policymakers, including a very high level of country coverage and a high degree of simplicity for the sake of transparency and duplication. This paper therefore devises an index which incorporates data that are available for a large number of countries, and which is easy to calculate and update. The inclusion of the 
specific components of the index, the proxies used to measure them and the robustness of the index rankings with respect to alternative weighting systems are discussed below.

Drawing on the review of the aid effectiveness literature presented above, the CIAC incorporates three major components of absorptive capacity: (i) capital constraints (including human capital and infrastructure constraints); (ii) governance constraints (including policy and institutional constraints); and (iii) donor practices. This choice of constraints as index components is strongly justified by the findings of the aid effectiveness literature concerning their importance. There is a very broad consensus throughout the literature that each of these constraints can hamper the use of additional aid. Moreover, data that can adequately measure these constraints is widely available for developing countries. While less importance is attached to the other two constraints discussed in Section 2 (macroeconomic and social/cultural), they might still be relevant to certain countries. Donors can augment the CIAC with other country specific information where appropriate.

These types of constraints, how they are measured and the source of data are presented in Table 1 below. Descriptive statistics for all of the variables are provided in Table A1 of the appendix. 
Table 1: Components of the index of absorptive capacity

\begin{tabular}{|c|c|c|c|}
\hline Component & Measurement & Source & Year \\
\hline \multicolumn{4}{|l|}{ Capital } \\
\hline Human capital & $\begin{array}{l}\text { (i) Number of doctors per thousand people } \\
\text { (ii) Number of nurses per thousand people } \\
\text { (iii) Number of primary school teachers per } \\
\text { thousand people } \\
\text { (iv) Number of secondary school teachers per } \\
\text { thousand people } \\
\text { (v) Adult illiteracy }\end{array}$ & World Bank (2009a) & $\begin{array}{l}\text { Latest } \\
\text { available }\end{array}$ \\
\hline Infrastructure & (i) Paved roads (per cent of total) & World Bank (2009a) & $\begin{array}{l}\text { Latest } \\
\text { available }\end{array}$ \\
\hline \multicolumn{4}{|l|}{ Governance } \\
\hline $\begin{array}{l}\text { Policy/ } \\
\text { institutional }\end{array}$ & $\begin{array}{l}\text { (i) Voice and accountability } \\
\text { (ii) Political instability } \\
\text { (iii) Government effectiveness } \\
\text { (iv) Regulatory quality } \\
\text { (v) Rule of law } \\
\text { (vi) Control of corruption }\end{array}$ & World Bank (2009b) & 2008 \\
\hline \multicolumn{4}{|l|}{ Donor } \\
\hline Donor practices & $\begin{array}{l}\text { (i) Ratio of the number of DAC donors to the log } \\
\text { of government expenditures. } \\
\text { (ii) Ratio of fragmentation (number of donors } \\
\text { accounting for less than } 10 \text { per cent of Country } \\
\text { Programmable Aid (CPA)) to the log of } \\
\text { government expenditures. }\end{array}$ & $\operatorname{OECD}(2009 a)$ & $\begin{array}{l}2005 / 06 \\
\text { average }\end{array}$ \\
\hline
\end{tabular}

The choice of the variables employed to measure the three constraints warrants some discussion. All of the variables provide important information relating to the key constraints that have been identified by the literature as hampering the effectiveness of foreign aid.

The health and education sectors are assuming ever greater importance as donors scale-up aid in attempts to achieve the MDGs. However, a shortage of skilled professionals in these sectors will limit the productive use of additional financial resources. Proxies for human capital constraints therefore include the number of doctors, nurses and primary and secondary school teachers per thousand people. A skilled civil service is also required to handle high levels of foreign aid. Much foreign aid is provided directly to recipient governments placing large administrative and other demands on government staff. An adult literacy variable is included as a proxy for the capacity of the staff in recipient public sectors. Physical capital constraints are captured by the extent of paved roads. This is justified on the grounds that a lack of road infrastructure will impede the 
delivery of basic services even when additional resources are available. To achieve the MDGs, more remote locations of recipient countries need to be targeted and poor road systems will increase the costs and weaken the viability of servicing remote communities.

Proxies for the policy and institutional constraints include the World Bank's governance indicators. These indicators have excellent coverage for developing countries, have been used in numerous empirical studies and are correlated with other measures of institutional strength. It is assumed that countries with low values for governance have less capacity to utilize additional aid flows effectively and that returns to aid funded investments will be lower. The quality of donor practices is measured using the number of donors providing aid to the recipient and the extent of aid fragmentation (both as a ratio to the log of government expenditures). These variables capture the donor imposed administrative burden associated with aid. The greater the number of donors and the higher the level of fragmentation, the more time recipient public sectors spend on aid administration. Although these constraints could be relieved over the long term (including through the use of aid), they will be binding in the short term, restricting the effectiveness of aid.

The sensitivity of country rankings from a composite index to the weightings attached to the index components must be examined. Three methods for weighting the different components (constraints) of the composite index are adopted. The sensitivity of country rankings and policy implications to these different methods are analysed and discussed in Section 4 below.

In the first method, an equally weighted index is constructed. Each of the 14 variables used to measure the four different constraints are standardised to lie between zero and one. ${ }^{8}$ The variables are averaged at a constraint level to provide an indication of the importance of the three different constraints at a country level. The values for the three different constraints are then combined with an equal weighting to calculate the CIAC. Using this method, the index is calculated for all 140 recipients of ODA (in 2007) even in cases where data are not available for all of the variables. The index is referred to as CIAC1.

\footnotetext{
8 The governance variables are constructed so that they have an effective range of -3 to 3 . These variables are scaled to lie in a range $(0,1)$ by adding 3 to each value then dividing it by six. A score of close to one (zero) indicates that the level of governance enables a high (low) level of absorptive capacity. A similar procedure is applied to the variables that represent capital constraints. Actual values are divided by the maximum value for each variable. This gives a score from zero to one where one (zero) indicates a high (low) level of absorptive capacity. For the donor constraint variable, the following formula was applied (maximum value-actual value)/maximum value. This was so that the score was reversed to provide a consistent interpretation with the other constraints.
} 
CIAC1 can be criticised on its equal weighting of its various components. At the same time, assigning different weights to the different dimensions of absorptive capacity must be readily justifiable. Factor analysis provides a useful and widely used method for calculating alternative weights for the index components, particularly when the variables used in the construction of an index are correlated. Factor analysis is a statistical technique that groups variables according to their degree of co-movement. Variables are grouped into (fewer) factors according to their comovements.

The latent components of the index of absorptive capacity are defined by the number and composition of the groupings. A (factor) score can be calculated at the constraint level and a composite index is devised by combining the factor scores for each country. Each factor indicates which set of variables have the most association with it. Two methods of combining the factor scores are utilised. The first takes a simple average of the factor scores and the resulting index is referred to as CIAC2. The second takes a weighted average of the factor scores, with the weights determined by the relative proportion of the total variance explained. This composite index is referred to as CIAC3. ${ }^{9}$ The Further details of the factor analysis are provided in the appendix.

\section{Analysis and discussion}

This section seeks to confirm that the composite index created by the paper is relevant to the analysis of aid effectiveness. This is achieved by employing the CIAC in a standard empirical growth model. ${ }^{10}$ Variable descriptions and their sources are provided in Table A2. The specification of the model largely follows that of Burnside and Dollar (2000), Hansen and Tarp (2001) and Rajan and Subramanian (2008). Unfortunately, data availability restricts the measurement of absorptive capacity through time. This paper calculates the CIAC using the latest available data from 2000. Since levels of absorptive capacity will change over time (albeit slowly), the sample period for empirical estimations is restricted to six 3-year periods from 1990 to 2005 .

Results from the estimation of the model using different estimation techniques are provided in Table 2. Column (1) provides results from the Least Squares Dummy Variables (LSDV) method

\footnotetext{
${ }^{9}$ Note that these indices cannot be calculated for countries with missing data for any of the variables.

10 Results presented below are for CIAC1 and are broadly very similar to the results for CIAC2 and CIAC3. Additional results are available from the author upon request.
} 
of estimating equation (1) (from Section 2 above). Aid variables are lagged one period to control for their potential endogeneity. Aid and aid-squared variables are included and confirm the finding of diminishing returns. The coefficients attached to these variables are positive and negative respectively and are statistically significant. In the second model the aid-squared variable is replaced with an aid*CIAC interaction. ${ }^{11}$ While the coefficient attached to the aid variable is negative, the positive and statistically significant coefficient attached to the aid-CIAC interaction term indicates that the impact of aid on growth is higher in recipients with higher levels of absorptive capacity. Results are provided in column (2). Column (3) presents the results from fixed effects estimation and the results with respect to aid are confirmed. Column (4) provides results from GMM system estimation, the preferred method of estimation by much of the recent literature which treats aid as endogenous. Results from GMM estimation pass the Arellano-Bond test for autocorrelation and the validity of instruments are confirmed using the Hansen $J$ - test for overidentifying restrictions. The coefficient attached to the aid-CIAC interaction terms is positive and statistically significant. All available lags are used as instruments but results remain unchanged with different instrument lag lengths. Overall, the results from these empirical estimations provide very strong support for the relevance of the index for policymakers.

\footnotetext{
${ }^{11}$ A high level of collinearity between the aid, aid squared and aid CIAC interaction variables prevents them from entering the same regression specification.
} 
Table 2: Empirical results (dependent variable is average annual growth of real per capita GDP (PPP))

\begin{tabular}{|c|c|c|c|c|}
\hline & $\begin{array}{c}(1) \\
\text { LSDV }\end{array}$ & $\begin{array}{c}(2) \\
\text { LSDV }\end{array}$ & $\begin{array}{l}\text { (3) } \\
\text { FE }\end{array}$ & $\begin{array}{c}\text { (4) } \\
\text { GMM-SYS }\end{array}$ \\
\hline Constant & $\begin{array}{c}10.151 \\
(5.39)^{* * *}\end{array}$ & $\begin{array}{c}2.586 \\
(1.66)^{*}\end{array}$ & $\begin{array}{c}3.630 \\
(6.23)^{* * *}\end{array}$ & $\begin{array}{c}4.692 \\
(4.86)^{* * * *}\end{array}$ \\
\hline Initial GDP per capita & $\begin{array}{c}-0.000 \\
(2.71)^{* * *}\end{array}$ & $\begin{array}{l}-0.000 \\
(0.87)\end{array}$ & $\begin{array}{c}-0.000 \\
(0.97)\end{array}$ & $\begin{array}{c}-0.000 \\
(0.38)\end{array}$ \\
\hline Ethnic fractionalisation & $\begin{array}{c}-14.363 \\
(3.54)^{* * *}\end{array}$ & $\begin{array}{l}-0.598 \\
(0.16)\end{array}$ & - & $\begin{array}{c}-2.795 \\
(2.52)^{* *}\end{array}$ \\
\hline Assassinations & $\begin{array}{c}-0.019 \\
(0.05)\end{array}$ & $\begin{array}{l}0.041 \\
(0.11)\end{array}$ & $\begin{array}{l}0.041 \\
(0.08)\end{array}$ & $\begin{array}{l}-0.135 \\
(0.45)\end{array}$ \\
\hline Ethnic*Assassinations & $\begin{array}{l}-0.586 \\
(0.74)\end{array}$ & $\begin{array}{l}-0.699 \\
(0.88)\end{array}$ & $\begin{array}{l}-0.699 \\
(0.57)\end{array}$ & $\begin{array}{l}0.028 \\
(0.04)\end{array}$ \\
\hline Inflation & $\begin{array}{c}-0.001 \\
(2.20)^{* *}\end{array}$ & $\begin{array}{c}-0.001 \\
(2.21)^{* *}\end{array}$ & $\begin{array}{c}-0.001 \\
(2.39)^{* *}\end{array}$ & $\begin{array}{c}-0.001 \\
(2.42)^{* *}\end{array}$ \\
\hline Trade openness & $\begin{array}{c}1.570 \\
(3.02)^{* * *}\end{array}$ & $\begin{array}{c}1.391 \\
(2.67)^{* * *}\end{array}$ & $\begin{array}{c}1.391 \\
(2.37)^{* *}\end{array}$ & $\begin{array}{c}1.236 \\
(2.65)^{* * *}\end{array}$ \\
\hline Aid to GDP (lagged) & $\begin{array}{c}0.189 \\
(2.15)^{* *}\end{array}$ & $\begin{array}{c}-0.465 \\
(2.95) * * *\end{array}$ & $\begin{array}{c}-0.465 \\
(3.01)^{* * *}\end{array}$ & \\
\hline Aid to GDP Squared (lagged) & $\begin{array}{c}-0.003 \\
(2.15)^{* *}\end{array}$ & & & \\
\hline Aid*CIAC (lagged) & & $\begin{array}{c}1.651 \\
(3.16)^{* * *}\end{array}$ & $\begin{array}{c}1.651 \\
(3.40)^{* * *}\end{array}$ & \\
\hline Aid to GDP & & & & $\begin{array}{l}-0.372 \\
(1.90)^{*}\end{array}$ \\
\hline $\mathrm{Aid}^{*} \mathrm{CIAC}$ & & & & $\begin{array}{c}1.411 \\
(2.00)^{* *}\end{array}$ \\
\hline Observations & 463 & 434 & 434 & 440 \\
\hline R-squared & 0.50 & 0.48 & - & - \\
\hline
\end{tabular}

The paper proceeds by examining the sensitivity of country rankings to different CIACs (with different constraint weightings). Table 3 below presents the rank correlations between the different aggregate indices of absorptive capacity. It indicates that there is a very high degree of correlation between the three different composite indices. This implies that rankings and policy recommendations based on rankings of absorptive capacity change very little with the index employed.

Table 3: Correlations between alternative methods

\begin{tabular}{rrr}
\hline & CIAC1 & CIAC2 \\
\hline CIAC2 & 0.95 & \\
CIAC3 & 0.87 & 0.97 \\
\hline
\end{tabular}

Note: Correlations are based on the 66 nations that are common to all three applications 
For the donor community, low levels of absorptive capacity in recipient countries constitute a particularly important issue if these countries are also receiving high levels of foreign aid. Table 4 below lists 15 countries which have low levels of absorptive capacity (with a CIAC1 score below 0.5 ) but receive high levels of foreign aid relative to their GDP (greater than 15 per cent).

Table 4: Countries with low absorptive capacity receiving high amounts of foreign aid

\begin{tabular}{lcc}
\hline Country & $\begin{array}{c}\text { ODA/GDP } \\
(\%)\end{array}$ & CIAC \\
\hline Liberia & 94.7 & 0.28 \\
Timor-Leste & 70.0 & 0.26 \\
Micronesia, Fed. Sts. & 48.3 & 0.50 \\
Burundi & 47.6 & 0.24 \\
Solomon Islands & 46.7 & 0.43 \\
Afghanistan & 38.9 & 0.13 \\
Guinea-Bissau & 32.3 & 0.28 \\
Sierra Leone & 32.2 & 0.28 \\
Sao Tome and Principe & 24.8 & 0.42 \\
Mozambique & 22.2 & 0.25 \\
Rwanda & 20.9 & 0.25 \\
Malawi & 20.5 & 0.31 \\
Kiribati & 19.8 & 0.39 \\
Iraq & 17.9 & 0.34 \\
Tanzania & 16.7 & 0.33 \\
\hline
\end{tabular}

Note: Countries listed are those with CIAC1 scores $<0.5$ and which receive a level of ODA exceeding 15 per cent of GDP. ODA data are sourced from the OECD (2011b).

Nine of the 15 countries are located in Africa and most are experiencing conflict or post-conflict episodes. Nonetheless, the list includes six SIDS, four of which are located in the Pacific (Kiribati, the Marshall Islands, Micronesia, and the Solomon Islands). The list also includes three countries located in Asia (Afghanistan, Iraq and Timor-Leste).

Another way of examining whether countries are receiving appropriate levels of aid is to estimate the specific threshold at which diminishing returns sets in for each individual country. In order to do this, it is assumed that for a country with an average CIAC, this threshold is where aid accounts for 20 per cent of a recipient's GDP. This is justified on the basis that aid growth studies find that this threshold exists for the average developing country. The threshold is adjusted for individual countries by scaling it by a factor equal to its CIAC score relative to the average CIAC. Results from this exercise are provided in Table 5. 
Table 5: Levels of ODA Versus Estimated Diminishing Return Thresholds

\begin{tabular}{lcc}
\hline Country & ODA/GDP $(\%)$ & $\begin{array}{c}\text { Estimated } \\
\text { ODA/GDP } \\
\text { Threshold }(\%)\end{array}$ \\
\hline Afghanistan & $\mathbf{3 8 . 9}$ & $\mathbf{6 . 5}$ \\
Burundi & $\mathbf{4 7 . 6}$ & $\mathbf{1 2 . 0}$ \\
Burkina Faso & 13.8 & 13.0 \\
Djibouti & 13.8 & 13.5 \\
Eritrea & 11.3 & 11.0 \\
Ethiopia & 12.5 & 12.0 \\
Micronesia, Fed. Sts. & $\mathbf{4 8 . 3}$ & $\mathbf{1 7 . 0}$ \\
Guinea-Bissau & $\mathbf{3 2 . 3}$ & $\mathbf{1 4 . 0}$ \\
Iraq & 17.9 & 17.0 \\
Kiribati & 19.8 & 19.5 \\
Liberia & $\mathbf{9 4 . 7}$ & 14.0 \\
Marshall Islands & 34.9 & 19.0 \\
Mali & 14.9 & 14.0 \\
Mozambique & 22.2 & 12.5 \\
Malawi & 20.5 & 15.5 \\
Niger & 12.8 & 12.5 \\
Rwanda & 20.9 & 12.5 \\
Solomon Islands & $\mathbf{4 6 . 7}$ & 12.5 \\
Sierra Leone & $\mathbf{3 2 . 2}$ & $\mathbf{1 4 . 0}$ \\
Sao Tome and Principe & 24.8 & 21.0 \\
Timor-Leste & $\mathbf{7 0 . 0}$ & 11.5 \\
Tanzania & 16.7 & 16.5 \\
Uganda & 14.5 & 14.0 \\
Congo, Dem. Rep. & 12.2 & 10.5 \\
\hline
\end{tabular}

Table 5 indicates that 24 countries received a level of aid in 2008 which exceeded their diminishing returns threshold. Importantly, eight countries are receiving a level of aid which is more than twice their estimated diminishing returns threshold. These countries are highlighted in bold. Drawing on Figure 1 presented earlier, these results imply that these countries might be experiencing negative (rather than diminishing returns) to foreign aid. As discussed in the conclusion below, donors should examine closely the levels and impacts of their assistance to these countries. $^{12}$

\footnotetext{
${ }^{12}$ Note that many (but not all) of these countries are low income countries If levels of absorptive capacity are highly correlated with income levels, this raises questions as to the usefulness of the CIAC as an additional variable to consider when allocating aid. The correlation coefficient between CIAC1 and GDP per capita is 0.71 . Furthermore, regressing CIAC1 on GDP per capita yields an R-squared of 0.50 . This implies that 50 per cent of the variation in CIAC1 is not explained by GDP per capita. Therefore, the CIAC clearly provides different and additional information vis-à-vis GDP per capita. Moreover, the ratio of disbursements to commitments is sometimes used to infer a level of absorptive capacity. If this ratio is low, it might indicate that a country is unable to spend its current level of aid due to bottlenecks and absorptive capacity constraints. Yet the ratio can also be influenced by emergency aid and the failure of donors to disburse such aid. The correlation between CIAC1 and this ratio of just -0.20 indicates that the disbursement to commitment ratio is a poor proxy for absorptive capacity. These findings remain unchanged when the other CIACs are used.
} 


\section{Conclusion and policy recommendations}

There is strong evidence to suggest that absorptive capacity constraints can hamper the effectiveness of foreign aid. This issue is becoming increasingly important as the international community scales up its level of assistance to developing countries. The issue of absorptive capacity therefore needs to be systematically considered by donors when allocating their aid otherwise there is a risk that additional aid flows will not lead to progress towards the MDGs or yield other desired outcomes. Disillusionment around foreign aid could spread, and support for future foreign assistance might weaken.

Existing models of aid allocation seek to allocate a fixed budget of funds across all developing countries according to their size, level of need and a measure of performance or ability to use aid effectively. Commonly, the measure of performance is determined by a country's policy and institutional environment. While this represents one component of a recipient's absorptive capacity, it is far too limited. As demonstrated by the paper, absorptive capacity relates to a number of recipient country characteristics. A CIAC is therefore devised which can augment aid allocation models and ensure a more appropriate global distribution of aid. The relevance of the index to aid effectiveness is confirmed in a growth regression and country rankings are robust to alternative weightings of the index components.

A number of countries are highlighted which have low levels of absorptive capacity but are receiving high levels of foreign aid. Levels of assistance to these countries should be examined closely to ensure desired outcomes are being achieved. These countries clearly do not provide a strong case for additional aid as donors continue to scale up.

While it can be argued that absorptive capacity constraints can be relieved by aid itself, this takes time and the effectiveness of aid at achieving this goal is sometimes questioned. Relieving human capital and policy and institutional constraints is particularly challenging and is only likely to occur over a long timeframe. In countries with low levels of absorptive capacity, donors must ensure their programs are either effectively relieving existing constraints or that they are working around them. 


\section{References}

Acharya, A., de Lima, A. and M. Moore (2006), Proliferation and fragmentation: transaction costs and the value of aid, Journal of Development Studies, Vol.42, No.1, pp.1-21.

Adenauer, I., and L. Vagassky (1998). Aid and the real exchange rate: Dutch disease effects in African countries. Intereconomics: Review of International Trade and Development, 33 (4): 177-85

Annen, K. and S. Kosempel (2009), Foreign aid, donor fragmentation, and economic growth, The B.E. Journal of Macroeconomics: Vol. 9, No.1, Article 33.

Arndt, C., Jones, S. and F. Tarp (2010), Aid, Growth, and Development: Have We Come Full Circle?, Journal of Globalization and Development, Vol. 1, No. 2, Article 5.

Azam, J.P., S. Devarajan and S.A. O’Connell (1999), Aid dependence reconsidered, World Bank Policy Paper No. 2144, World Bank, Washington.

Barder, O (2006), A policymakers' guide to Dutch disease, Center for Global Development Working Paper No. 91, Center for Global Development, Washington.

Bourguignon, F. Gelb, A and B. Versailles (2005), Policy, aid and performance in Africa: the G11 and other country groups. Forthcoming World Bank Working Paper, Washington.

Bourguignon, F. and M. Sundberg (2006), Constraints to achieving the MDGs with scaled-up aid, DESA Working Paper No. 15, United Nations Department of Economic and Social Affairs, New York.

Bräutigam, D. 2000, Aid dependence and governance, Almqvist and Wiksell, Stockholm.

Bräutigam, D. and S. Knack (2004), Foreign aid, institutions and governance in Sub-Saharan Africa, Economic Development and Cultural Change, Vol.52, No.2, pp.255-86.

Bulír, A. and A. J. Hamann (2008), Volatility of development aid: from the frying pan into the fire?_World Development, Vol, 36, No.10, pp.2048-2066.

Burnside, C. and D. Dollar (2000), Aid, policies and growth, American Economic Review, Vol.90, No.4, pp.847-868.

Burnside, C. and D. Dollar (2004), Aid, policies and growth: revisiting the evidence, World Bank Policy Research Working Paper No 3251, World Bank, Washington.

Chenery, H. and Strout, A.M., (1966), Foreign assistance and economic development, American Economic Review, Vol. 56, No.4, pp.679-733.

Clemens, M. and S. Radelet (2003), Absorptive capacity: how much is too much?, in S. Radelet (ed.), Challenging foreign aid: a policymaker's guide to the millennium challenge account, Center for Global Development, Washington.

Clemens, M., S. Radelet and R. Bhavani (2004), Counting chickens when they hatch: the shortterm effect of aid on growth, Center for Global Development Working Paper Number 44. 
Clemens, M., Kenny, C. and T. Moss (2007), The trouble with the MDGs: confronting expectations of aid and development success, World Development, Vol.35, No.5, pp.735-51.

Cogneau, D. and J-D. Naudet (2007), Who deserves aid? equality of opportunity, international aid and poverty reduction, World Development, Vol.35, No.1, pp.104-120.

Collier, P. (2007), The bottom billion, Oxford University press, Oxford.

Collier, P and D. Dollar (2002), Aid allocation and poverty reduction, European Economic Review, Vol.46, pp.1475-1500.

Collier, P. and A. Hoeffler (2004), Aid, policy and growth in post-conflict societies, European Economic Review, Vol.48, No.5, pp.1125-1145.

Coviello, D and R. Islam (2006), Does aid help improve economic institutions?, World Bank Policy Research Working Paper 3990, World Bank, Washington.

DAC (2009a), International development statistics online database, Development Assistance Committee of the OCED, Paris.

DAC (2009b), Development cooperation report 2009, Development Assistance Committee of the OECD, Paris.

Dalgaard, C-J and H Hansen (2001), On aid, growth and good policies, Journal of Development Studies, Vol.37, No.6, pp.17-35.

Dalgaard, C-J, H. Hansen and F. Tarp (2004), On the empirics of foreign aid and growth, Economic Journal, Vol.114, pp.191-216.

de Renzio, P (2005), Increased aid versus absorptive capacity: challenges and opportunities towards 2015, IDS Bulletin, Vol.36, No3, pp.14-19

Dollar, D. and V. Levin (2005), The forgotten states: aid volumes and volatility in difficult partnership countries, Paper Prepared for the Development Assistance Committee (DAC) Learning and Advisory Process On Difficult Partnerships. OECD, Paris.

Dreesch, N, Dolea, C., DalPoz, M., Goubarev, A., Adams, O., Aregawi, M., Bergstrom, K., Fogstad, H., Sheratt, D., Linkins, J., Scherpbier, R. and M. Youssef-Fox (2005), An approach to estimating human resource requirements to achieve the Millennium Development Goals, Health Policy and Planning, Vol.20, pp.267-76.

Easterly, W., Levine, R., and D. Roodman (2004), New data, new doubts: a comment on Burnside and Dollar's “Aid, policies and growth (2000)". American Economic Review, Vol.94, No.3, pp.781-784.

Feeny, S. and M. McGillivray (2010), Aid and growth in small island developing states, Journal of Development Studies, forthcoming.

Feeny, S. and M. McGillivray (2011), Scaling-up foreign aid: will the 'big push' work?, The World Economy, Vol.34, No.1, pp 54-73. 
Fielding, D. (2007) Aid and Dutch disease in the South Pacific, United Nations University World Institute for Development Economics Research (UNU-WIDER), Research Paper No. 2007/50, Helsinki.

Fielding, D. and Mavrotas, G. (2008), The volatility of aid, Economica, Vol.75, No. 299, pp.48194.

Guillaumont P, and L. Chauvet (200), Aid and performance: a reassessment, Journal of Development Studies, Vol. 37, No.6, pp.66-87.

Gupta, S., Powell, R. and Y. Yongzheng (2006), Macroeconomic challenges of scaling up aid to Africa: a checklist for practitioners, International Monetary Fund, Washington.

Hansen, H and F Tarp (2000), Aid effectiveness disputed, Journal of International Development, Vol.12, pp.375-398.

Hansen, H and F Tarp (2001), Aid and growth regressions, Journal of Development Economics, Vol.64, pp.547-570.

Heller, P.S. (2005), Pity the finance minster: issues in managing a substantial scaling up of aid flows, IMF Working Paper No. Wp/05/180, International Monetary Fund, Washington.

Hudson, J. and P. Mosley (2001), Aid, policies and growth: in search of the Holy Grail, Journal of International Development, Vol.13, pp.1023-1038.

Killick, T (2005), Don't throw money at Africa, IDS Bulletin, Vol.36, No.3, pp.14-19.

Killick, T. and M. Foster (2007), The macroeconomics of doubling aid to Africa and the centrality of the supply side, Development Policy Review, Vol.25, No.2, pp.167-192.

Knack, s. (2000), Aid dependence and the quality of governance: a cross-country empirical analysis, World Bank Policy Research Working Paper No. 2396, World Bank, Washington.

Knack, S and A, Rahman (2004), Donor fragmentation and bureaucratic quality in aid recipients, World Bank Policy Research Working Paper No. 3186, World Bank, Washington.

Laplange, P., M. Treadgold, and J. Baldry (2001). A model of aid impact in some South Pacific microstates. World Development, 29 (2): 365-83.

Lensink, R. and O. Morrissey (2000), Aid instability as a measure of uncertainty and the positive impact of aid on growth, Journal of Development Studies, Vol.36, No.3, pp.31-49.

Lensink, R and H White (2001), Are there negative returns to aid?, Journal of Development Studies, Vol.37, No.6, pp.42-64.

Llavador, H.G. and J.E. Roemer (2001), An Equal Opportunity Approach to the Allocation of International Aid, Journal of Development Economics, Vol.64, pp.147-171.

McGillivray, M. and S. Feeny (2008), Aid and growth in fragile states, United Nations University World Institute for Development Economics Research (UNU-WIDER), Research Paper No. 2008/03, Helsinki. 
Morss, E.R. (1984), Institutional destruction resulting from donor and project proliferation in Sub-Saharan African countries, World Development, Vol.12, No.4, pp.465-70.

Moss, T, Pettersson, G. and N. van de Walle (2006), An aid institutions paradox? a review essay on aid dependency and state building in Sub-Saharan Africa, Center for Global Development Working Paper Number 74, Center for Global Development, Washington.

Nyoni, T. S. (1998). Foreign aid and economic performance in Tanzania. World Development, 26: 1235-1240.

OECD (2008), 2008 Survey on Monitoring the Paris Declaration, OECD, Paris.

Organisation for Economic Co-operation and Development (OECD) (20011a), Development aid rose in 2009 and most donors will meet 2010 aid targets, OECD, Paris (viewed 30/08/2011). http://www.oecd.org/document/0,3746,en_2649_34447_44981579_1_1_1_1,00.html

Organisation for Economic Co-operation and Development (OECD) (2011b), International Development Statistics On-line, OECD, Paris.

Ouattara, B. and E. Strobl (2003), Do aid inflows cause Dutch Disease? a case study of the CFA Franc countries, The School of Economics Discussion Paper Series 0330, Economics, The University of Manchester.

Rajan, R.G. and A. Subramanian (2005), What undermines aid's impact on growth?, IMF Working Paper 05/126, International Monetary Fund, Washington.

Rajan, R.G. and A. Subramanian (2008), Aid and growth: what does the cross-country evidence Really Show?, Review of Economics and Statistics, Vol.90, 4, 643-65.

Ravallion, M. (2010), Mashup Indices of Development, World Bank Policy Research Working Paper 5432, World Bank, Washington.

Reyes, R. A. (1993), Absorptive capacity for foreign aid: the case of the Philippines, International Center for economic growth and the Philippine Institute for Development Studies, Manila.

Roodman, D. (2004), The anarchy of numbers: aid, development and cross-country empirics, CGD Working Paper No. 32, July 2004, Centre for Global Development, Washington, D.C.

Roodman, D (2006), Aid project proliferation and absorptive capacity, CGD Working Paper No. 75, Centre for Global Development, Washington, D.C.

Sackey, H. A. (2001). External aid flows and the real exchange rate in Ghana AERC Paper No. 110. Nairobi: African Economic Research Consortium.

Stockmayer, A. (2005), The state and governance: the main bottlenecks for absorbing massively increased aid?, IDS Bulletin, Vol.36, No.3, pp68-73.

Svensson, J. (1999), Aid, Growth and Democracy, Economics and Politics, Vol.11, No.3, pp.275-97.

Tavares, J. (2003), Does foreign aid corrupt, Economics Letters, Vol.79, 1, 99- 106. 
White, H., and G. Wignaraja (1992). 'Exchange rates, trade liberalization and aid: the Sri Lankan experience'. World Development, 20 (10): 1471-80.

Wood, A. (2008), Looking ahead optimally in allocating aid, World Development, Vol.36, No.7, pp.1135-51.

World Bank (2009a), World development indicators online database, World Bank, Washington

World Bank (2009b), Worldwide governance indicators online database, World Bank, Washington 


\section{Appendix}

Table A1: Descriptive statistics for absorptive capacity constraint variables

\begin{tabular}{lccccc}
\hline Variable & Minimum & Maximum & Median & Mean & $\begin{array}{c}\text { Standard } \\
\text { Deviation }\end{array}$ \\
\hline Primary school teachers per 1000 people & & & & & 1.32 \\
Secondary school teachers per 1000 people & 0.55 & 11.70 & 4.91 & 5.14 & 1.92 \\
Paved roads (per cent of total) & 0.80 & 100.00 & 27.80 & 38.39 & 30.25 \\
Doctors per 1000 people & 0.02 & 5.91 & 0.49 & 0.98 & 1.16 \\
Nurses per 1000 people & 0.19 & 12.51 & 1.50 & 2.33 & 2.51 \\
Adult literacy & 26.18 & 99.79 & 84.28 & 77.79 & 20.03 \\
Voice and accountability & -2.24 & 1.24 & -0.29 & -0.40 & 0.80 \\
Political instability & -3.28 & 1.40 & -0.21 & -0.36 & 0.87 \\
Government effectiveness & -2.51 & 1.48 & -0.56 & -0.48 & 0.63 \\
Regulatory quality & -2.77 & 1.58 & -0.46 & -0.48 & 0.70 \\
Rule of law & -2.69 & 1.28 & -0.54 & -0.49 & 0.64 \\
Control of corruption & -1.90 & 1.32 & -0.53 & -0.46 & 0.59 \\
Number of donors & 2 & 30 & 20 & 18.12 & 6.52 \\
Fragmentation & 0 & 25 & 13 & 12.17 & 5.63 \\
Donors/log(Govt Exp.) & 0.12 & 1.44 & 1.01 & 0.95 & 0.34 \\
Fragmentation/log(Govt Exp.) & 0.04 & 1.02 & 0.7 & 0.66 & 0.28 \\
\hline
\end{tabular}

Notes: See Table 1 for Variable Description, sample size varies between 115 and 140.

Table A2: Description and source of variables used in the empirical analysis

\begin{tabular}{|c|c|c|}
\hline Variable & Description & Source \\
\hline GDP per capita growth & $\begin{array}{l}\text { Annual average growth in real GDP per capita } \\
\text { (PPP) }\end{array}$ & Penn World Tables \\
\hline Initial GDP per capita & $\begin{array}{l}\text { GDP per capita (PPP) at the beginning of each } \\
\text { period (logged) }\end{array}$ & World Bank (2010) \\
\hline Ethnic fractionalisation & $\begin{array}{l}\text { Chance that two people drawn at random from } \\
\text { the population will speak the same language }\end{array}$ & Roodman (2004) \\
\hline Assassinations & Number of assassinations per capita & Roodman (2004) \\
\hline Population & Population & World Bank (2010) \\
\hline Inflation & $\begin{array}{l}\text { Average annual rate of growth in the Consumer } \\
\text { Price Index (CPI) }\end{array}$ & World Bank (2010) \\
\hline Trade & $\begin{array}{l}\text { Sachs-Warner trade openness index. (values for } \\
1998 \text { used for years after 1998) }\end{array}$ & Roodman (2004) \\
\hline Aid to GDP & $\begin{array}{l}\text { Ratio of Net Official Development Assistance } \\
\text { (ODA) to GDP }\end{array}$ & OECD (2010) \\
\hline CIAC1, CIAC2, CIAC3 & Composite Indices of Absorptive Capacity & Authors calculations \\
\hline
\end{tabular}




\section{Factor analysis}

The calculation of CIAC2 includes all 14 variables listed in Table A3 and is calculated for 90 countries. Presented below is the factor loading matrix with three columns, each representing a latent component of absorptive capacity.

Table A3: Factor Loading Matrix (N=66)

\begin{tabular}{lrrr}
\hline Variable & $\begin{array}{c}\text { Governance } \\
\text { (Factor 1) }\end{array}$ & $\begin{array}{c}\text { Capital } \\
\text { (Factor 2) }\end{array}$ & $\begin{array}{c}\text { Donors } \\
\text { (Factor 3) }\end{array}$ \\
\hline Primary school teachers per 1000 people & 0.206 & & -0.527 \\
Secondary school teachers per 1000 people & & 0.863 & -0.206 \\
Paved roads (per cent of total) & & 0.565 & -0.138 \\
Doctors per 1000 people & & 0.93 & \\
Nurses per 1000 people & & 0.823 & \\
Adult literacy & 0.282 & 0.709 & \\
Voice and accountability & 0.62 & -0.113 & \\
Political instability & 0.61 & 0.25 & -0.254 \\
Government effectiveness & 0.936 & 0.147 & \\
Regulatory quality & 0.859 & 0.159 & 0.101 \\
Rule of law & 0.92 & & -0.19 \\
Control of corruption & 0.893 & & -0.211 \\
Number of donors & & -0.372 & 0.88 \\
Fragmentation & & -0.213 & 0.946 \\
\hline
\end{tabular}

Note: Factor Loadings between -0.1 and 0.1 are supressed

The numbers in Table A3 are typically referred to as factor loadings. These loadings can be thought of as correlations, in particular, how the variables correlate with a particular factor. Loadings above 0.5 in magnitude are highlighted to help identify the different factors. The first factor has been denoted as Governance as the variables that define this factor (i.e. that have the highest loading) all relate to governance.

The second factor clearly measures Capital, as all the variables that load highly define the stock of physical and human capital. The third factor, Donors, primarily measures donor characteristics. This last factor is also determined by the number of primary school teachers per 1000 people. While it is expected that this variable belongs in the Capital factor, it is only marginally above 0.5 in magnitude and can be attributed to an aberration in the data rather than as a variable which defines the factor.

Unlike the first two factors, Donors measures the lack of absorptive capacity. As the level of Governance and Capital increases, a country's ability to absorb aid increases. However, as the number and fragmentation of donors increase a nation's capacity to absorb aid would be 
expected to decrease. This negative relationship is consistent with the negative factor loading of primary school teachers.

In order to increase the sample of countries for which CIAC3 is created, two variables are omitted from the analysis: adult literacy and paved roads. The results of this exercise are presented in Table A4 below.

Table A4: Factor Loading Matrix $(\mathrm{N}=82)$

\begin{tabular}{lrrr}
\hline Variable & $\begin{array}{c}\text { Governance } \\
\text { (Factor 1) }\end{array}$ & $\begin{array}{c}\text { Donors } \\
\text { (Factor 2) }\end{array}$ & $\begin{array}{c}\text { Capital } \\
\text { (Factor 3) }\end{array}$ \\
\hline Primary school teachers per 1000 people & 0.281 & -0.485 & \\
Secondary school teachers per 1000 people & & -0.213 & 0.854 \\
Doctors per 1000 people & & & 0.872 \\
Nurses per 1000 people & & -0.148 & 0.781 \\
Voice and accountability & 0.665 & -0.132 & \\
Political instability & 0.553 & -0.372 & 0.112 \\
Government effectiveness & 0.943 & & 0.14 \\
Regulatory quality & 0.87 & & 0.166 \\
Rule of law & 0.919 & -0.211 & \\
Control of corruption & 0.897 & -0.241 & \\
Number of donors & -0.106 & 0.913 & -0.25 \\
Fragmentation & & 0.988 & -0.108 \\
\hline
\end{tabular}

Note: Factor Loadings between -0.1 and 0.1 are supressed

An important feature of this table is that the factors are defined in the same way as in Table A3. This is despite the inclusion of an additional 16 countries. Therefore, the latent variables Governance, Donor and Capital appear to provide robust factors. The only discernable difference between Tables A5 and A6 is that the order in which the factors appear has changed. This indicates that the relative importance of the factors has changed (albeit marginally). Importance is typically measured by the proportion of variance explained. In both cases the three factors collectively explain at least 70 per cent of the variation in the dataset; and in both cases the Governance factor captures approximately 30 per cent of the variation. In the first application the Donor factor captures 16 per cent of the variation whereas in the second instance it represents 20 per cent of the variation. The results for Capital are 24 percent and 19 percent for the first and second applications respectively.

In Table A5 the correlations between the individual constraints from CIAC1, CIAC2 and CIAC3 are presented. The results in this table indicate that there is a high correlation between all three methods. This implies that the simple CIAC1 methodology is providing very similar information as the approaches based on factor analysis denoted by CIAC2 and CIAC3. 
TableA5: Correlations at the factor level

Governance (CIAC1) Governance (CIAC3)

\begin{tabular}{lcc}
\hline Governance (CIAC2) & 0.96 & 0.99 \\
Governance (CIAC3) & 0.95 & \\
\hline & & Capital (CIAC3) \\
\hline & Capital (CIAC1) & 0.99 \\
\hline Capital (CIAC2) & 0.96 & \\
Capital (CIAC3) & 0.93 & Donor (CIAC3) \\
\hline & & 0.99 \\
\hline Donor (CIAC2) & 0.96 & \\
\hline
\end{tabular}

Note: Correlations are based on the 66 countries that are common to the three indices. 